DOI: $10.17516 / 1997-1370-0588$

УДК 336.2

\title{
Assessment of the Sustainability of Budget Revenues in the Regions of the Russian Federation
}

\author{
Marina Yu. Malkina* \\ Lobachevsky State University of Nizhny Novgorod \\ Nizhny Novgorod, Russian Federation
}

Received 11.11.2019, received in revised form 03.03.2020, accepted 13.04.2020

\begin{abstract}
The paper proposes new approaches to assessing the sustainability of budget revenues in a region, which have been tested on the example of 83 subjects of the Russian Federation in 2010-2017. The sustainability of budget revenues is estimated on the basis of time series of two indicators: the ratio of sub-federal budget revenues to GRP and real income of sub-federal budgets per capita. To exclude economies of scale and eliminate system-wide risk, both indicators are calculated as a ratio to average Russian values. Using the construction of temporary linear regressions, a steady growth rate, absolute risk and relative risk of budget revenues are determined. For a comprehensive assessment of the sustainability of budget revenues in a region, we proposed the Arrow-Pratt function with the incorporated risk aversion parameter of 1.5.

Using the proposed technique, we evaluated the absolute and relative risk, as well as the sustainability of budget revenues in the Russian regions. Assessments based on the two alternative indicators showed a high correlation. Our study revealed that the least stable budget systems are typical for some border regions, including the backward North Caucasian republics and Far Eastern regions with an unstable economy, and Tyumen Oblast, which is quite developed, but depends on the world market. At the same time, some extractive regions (Republic of Sakha), on the contrary, showed a high stability of budget revenues.
\end{abstract}

Keywords: fiscal sustainability, region, sub-federal budget, budget revenue, risk and return of the budget system.

The reported study was funded by RFBR according to the research project No. 19-01000716 "Development of methodology and non-traditional methods for assessing financial instability".

Research area: economics.

Citation: Malkina, M.Yu. (2020). Assessment of the sustainability of budget revenues in the regions of the Russian Federation. J. Sib. Fed. Univ. Humanit. Soc. Sci., 13(4), 547-559. DOI: 10.17516/19971370-0588.

(C) Siberian Federal University. All rights reserved

* Corresponding author E-mail address: mmuri@yandex.ru

ORCID: 0000-0002-3152-3934 


\section{Introduction}

The fiscal sustainability of a country or region is a guarantee of timely and uninterrupted supply of public goods to the population, which, in turn, affects the growth of labor productivity and improving people's living standards. It also affects the long-term stability of the public debt. Fiscal sustainability of a particular territorial entity depends on the characteristics of its fiscal policy and the quality of administration of budget revenues and expenditures, as well as on the sectoral structure of economy, the degree of economic openness, etc.

The sustainability of regional budget revenues, which is the subject of this paper, is an essential component of overall fiscal sustainability. The purpose of this research is to clarify the concept of sustainability of regional budget revenues, improve approaches to its assessment and test them on data from Russian regions.

\section{Literature Review}

Economists do not have a unanimous opinion on what fiscal sustainability of a country or region is. Most scientists believe that fiscal sustainability is the ability of the public sector to meet its financial obligations (Bohn, 2008). Some of them suggest that the concept of fiscal sustainability cover two areas: budget balance and accumulated debt (Andryakov, 2017: 35). Others (Klimanov, Kazakova, Mikhaylova, 2018) analyze different approaches to determining the sustainability of territorial entities and the factors that ensure it. Meanwhile, all researchers recognize that budget revenues are a key component of overall fiscal sustainability.

Our research is based on two groups of studies related to our topic.

The first group embraces works devoted to assessment of the overall sustainability of regional economies. Various scholars proposed a number of methods for calculating the composite index of sustainable development, based on arithmetic, geometric or entropy generalizations (Rahma et al., 2019). A team of Russian scientists (Klimanov, Kazakova, Mikhaylova, 2019) developed an integrated index of regional resilience, which is the arithmetic mean of 6 specific indicators normalized to their standard deviation. In their study they confirmed the in- terconnection of budgetary and socio-economic sustainability of Russian regions in 20072016. Another researcher (Sheremeta, 2020) proposed a comprehensive evaluation of the fiscal sustainability of Russian regions based on various components of budget revenues and expenditures, as well as public debt. The author applied the k-means method to cluster Russian regions by the level of fiscal sustainability.

It should be noted that the above works are based on a resource approach and use static analysis methods. In our study, we do not follow a static, but a dynamic approach to determining fiscal sustainability, which is based on identification of fluctuations in budget returns relative to some systemic trend. This approach also has a number of adherents.

For example, (Smetana et al., 2015) proposed to combine the resource assessment in regions with the study of the cyclicality of complex systems. Other authors (Ivanov, Sakhapova, 2014) involved a dynamic approach for a comprehensive assessment of the financial instability of Russian regions and distinguished three methods for measuring the volatility of individual indicators: standard deviation, coefficient of variation, and Value at Risk (VaR). In another paper (Gambarov, Musayeva, Krupkina, 2017), the scholars compared alternative techniques of building a composite index of financial stress: variance-equal weighting method, portfolio theoretic aggregation method and principal component analysis.

The second group of relevant studies covers works devoted to factors of fiscal sustainability of Russian regions. They emphasize the high degree of differentiation of the socio-economic conditions of Russian regions and the problems of redistribution of budget resources between the levels of the budget system (Di Bella, Dynnikova, Grigoli, 2018; Bozhechkova et al., 2018). These studies are useful in explaining the budget instability of some regional economies.

Finally, our current research relies on a number of our own studies that examined the financial instability of the Russian regions economies. In these works, we applied a portfolio approach to decompose financial instability by industry (Malkina, 2018a, b) and proposed 
methods for managing it through optimization of the sectoral structures of regional economies (Malkina, 2019).

In this study, we develop the theory and methodology of fiscal sustainability in some aspects. First, we examine two indicators of the regional budget sphere, namely, the ratio of budget revenue to GRP and real budget revenue per capita. Secondly, we determine the ratio of each indicator in the region to its country level in order to eliminate systemic risk. Thirdly, we separate the volatility of relative indicators from their trends by construction of linear regressions and thereby achieve the stationarity of time series. Fourth, we use the Arrow-Pratt function, which is well known in investment analysis, to assess the overall sustainability of regional budget revenues. This allows us to synthesize the volatility of budget revenues and their steady growth rates on a new basis.

\section{Data and Methods}

We used data on revenues of consolidated budgets of 83 subjects of the Russian Federation in 2010-2017, provided by the Federal Treasury of the Russian Federation. We also applied statistics from the Federal State Statistics Service of the Russian Federation on GRP, average population, cost of the fixed consumer basket in the regions and in the country.

The choice of indicators for assessing the risk of budget revenues was based on their compliance with the requirement of stationarity of time series.

One of the indicators that can satisfy stationary property, is the ratio of budget revenues in the $\mathrm{i}$-th region $\left(B_{i}\right)$ to the GRP of this region $\left(Y_{i}\right)$ (hereinafter referred to as budget return):

$b_{I i}=B_{i} / Y_{i}$.

We can also consider the ratio of budget revenues to population. Indeed, budget revenues are used to provide residents of a certain territory with public goods. In this case, we should take into account two important features of the budget process.

Firstly, budget expenditures consist of a fixed part (depending on parameters other than the population, such as area, and infrastructure costs are an example of this) and a variable part (depending on the number of inhabitants in the region). Due to the fixed part, budget expenditures per capita in small regions with a large territory are objectively higher. That is why Chukotka Autonomous Okrug, the region with the highest level of per capita budget revenues, meanwhile, is subsidized from the federal budget.

Secondly, the cost of living and price level differ in the regions. This affects the cost of production of public goods in them. To eliminate the inflationary component of income, we calculate the real budget revenue per capita:

$$
b_{I I i}=B_{i} / I_{i} / N_{i},
$$

where $I_{i}=C L_{i} / C L_{i}$ is the index of the relative cost of living in the region, which is the ratio of the cost of a fixed consumer basket in the i-th region to the cost of the same basket in the country on average. $N_{i}$ is the average population of the i-th region in the corresponding period.

In further calculations, we use both relative indicators, $b_{I i}$ and $b_{I I i}$.

Although relative indicators better meet the stationarity requirement, they can still have a pronounced tendency. Since the economy develops cyclically, the dynamics of budget return in each particular region reflects the influence of both systemic risk and the specific risk characteristic of this region. To eliminate the systematic risk, we calculate the ratio of the regional budget return to the average return of the regional budgets in the country:

$$
r_{i}=b_{i} / \bar{b} \text {. }
$$

To separate the volatility from the trend in the time series of this indicator, we construct for each i-th region its linear dependence on time:

$$
r_{i t}=\underbrace{\alpha_{0}+\alpha_{1} \cdot t}_{r_{i t}}+e_{i t}
$$

where $\alpha_{0}$ and $\alpha_{1}$ are the estimated regression coefficients, $\hat{r_{i t}}$ are the budget return estimates, $e_{i t}$ are regression residuals.

Based on regression estimates, we determine the main budget parameters: 
- average relative budget return in the region: $\mu_{r}=\frac{1}{T} \sum_{t=1}^{T} r_{i t}=\frac{1}{T} \sum_{t=1}^{T} \hat{r_{i t}}$. If this parameter is greater than or equal to 1 , the state of the regional budget should be assessed positively, otherwise it should be assessed negatively;

- absolute budget risk is calculated as the standard deviation of the regression residuals: $\sigma_{e}=\sqrt{\operatorname{Var}\left(e_{i t}\right)}=\sqrt{\operatorname{Var}\left(r_{i t}\right)-\operatorname{Var}\left(\hat{r_{i t}}\right)}$. This parameter characterizes a non-systemic (specific) budget risk;

- relative budget risk, representing the ratio of absolute risk to average actual or estimated relative budget return: $v_{r}=\frac{\sigma_{e}}{\mu_{r}}$. Assuming a direct relationship between return and risk, we can argue that the relative indicator better reflects the state of sustainability of the public sector;

- steady growth rate of relative budget return is evaluated by trend line slope, $\alpha_{1}$. The positive value of this parameter is evaluated positively, and vice versa.

A general assessment of the sustainability of regional budget revenues should combine both steady growth rates of relative budget return and its volatility, that is, relative budget risk. For this purpose, we can use the Arrow-Pratt function, which in our case takes the form:

$$
f=\alpha_{1}-\frac{\beta}{2} \cdot v_{r},
$$

where $\beta$ is the risk aversion coefficient. Following the recommendations of the portfolio approach, we can accept its value equal to 1.5.

\section{Results and their analysis}

First of all, we computed the relative return of sub-federal budgets of all 83 subjects of the Russian Federation under review in dynamics for 8 years (2010-2017).

In the framework of the first approach, we assessed the budget return as the ratio of sub-federal budget revenues to GRP. The maximum deviations of this indicator from the average Russian level were found in the lagging re- publics of the North Caucasus and some border regions of the Siberian and Southern federal districts. For instance, in Republic of Ingushetia, the ratio of budget return to country level ( $b_{I i}$ ) amounted to 5.77, in Chechen Republic 5.07, in Republic of Tuva - 3.18, in Altai Republic - 3.08, in Republic of Kalmykia - 2.23. This is due to both the low level of GRP in these regions and the high level of inter-budgetary transfers to them from the federal budget.

Highly developed extractive regions and the capital city, on the contrary, showed the lowest values of relative budget returns. In particular, the average annual relative return of sub-federal budgets in Nenets Autonomous Okrug was only 0.31 , in Khanty-Mansi Autonomous Okrug - 0.38, in Yamal-Nenets Autonomous Okrug - 0.56, in Moscow - 0.61. This can be explained by the high level of GRP in these regions and their role as donors of budgetary resources for other regions.

In the framework of the second approach, we assessed the relative real revenue of sub-federal budgets per capita. Unlike the first approach, the maximum budget return turned out to be in the extractive regions. For example, in Chukotka Autonomous Okrug, the regional level of budget return was 4.15 times higher than the country level. In Nenets Autonomous Okrug this ratio was 3.95, in Yamalo-Nenets Autonomous Okrug - 3.12, in Sakhalin Oblast - 2.73, in Republic of Sakha (Yakutia) 2.15, and in Magadan Oblast - 2.12. The excess of real budget revenues per capita over the national average in the Far Eastern regions is partly due to a higher level of their prices, the influence of which is not completely eliminated when using the adopted income deflation procedure.

At the same time, the lowest level of budget return, according to the second approach, was marked in some regions of Southern and North Caucasian federal districts. Specifically, real budget revenue per capita in Stavropol Krai was only 0.54 of the Russian level, in Republic of Dagestan - 0.55, in Kabardino-Balkarian Republic -0.63 , in Rostov Oblast - 0.64, and in Republic of North Ossetia-Alanya - 0.65. Low values of this indicator also appeared in some lagging regions of Central and Volga Feder- 
al Districts: Ivanovo Oblast (0.62), Volgograd Oblast (0.64), and Vladimir Oblast (0.65).

Next, we present the results of regression estimations (4) obtained within two alternative approaches. Fig. 1 shows the assessments of absolute risk of sub-federal budgets in accordance with the first approach. Among the most risky regions in terms of the volatility of relative budget revenues to GRP, we again find the backward republics of southern Russia, as well as some subjects of Far Eastern Federal District. It is noteworthy that almost all of them are border regions. Thus, in Republic of Ingushetia, the absolute risk of the sub-federal budget reaches $47.9 \%$, while the average relative budget return in this republic is $576.6 \%$. This region is followed by Altai Republic (with absolute risk of $27.7 \%$ ), Chechen Republic (26.8\%), Sakhalin Oblast (22.5\%), Jewish Autonomous Oblast (20.5\%), and Republic of Tyva (20.1\%).
The least risky, according to the first approach, are the sub-federal budgets of the Saratov Oblast (1.1\%), Perm Krai (1.4\%) and Sverdlovsk Oblast (1.6\%). It should be noted that these regions are characterized by a rather diversified sectoral structure of the economy.

Further analysis revealed a fairly pronounced direct correlation between the average value of the relative return of the sub-federal budgets in the regions and their risk level (Fig. 2). This dependency is consistent with the theoretical relationship between risk and return.

The results of calculation of the relative risk of sub-federal budgets for all regions are shown in column 1 of the Table. Since relative risk takes into account the level of return around which fluctuations occur, the positions of the regions have changed somewhat. Now the leaders in the risk of sub-federal budgets

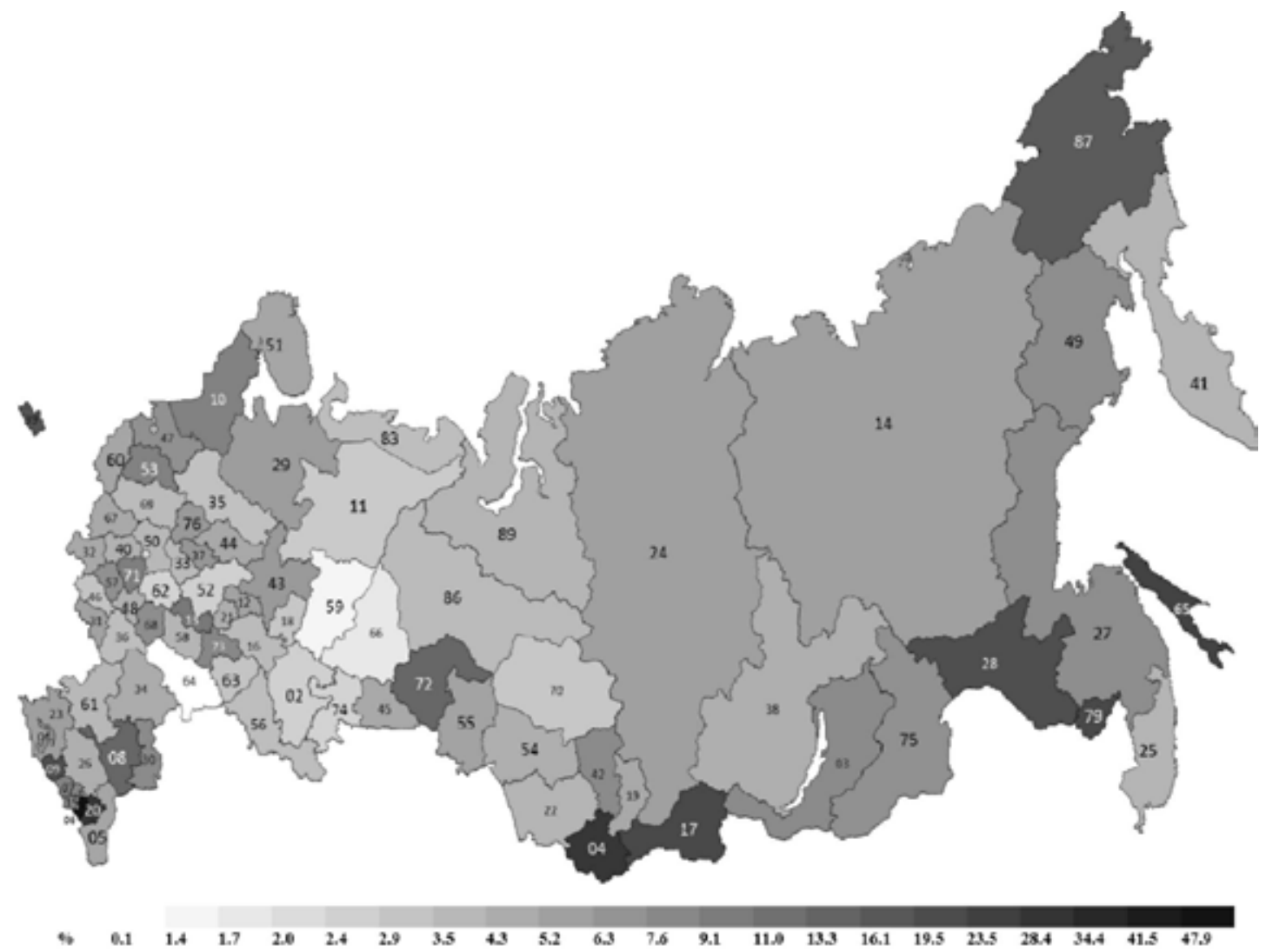

Fig. 1. Absolute risk of sub-federal budgets (measured on the basis of the ratio of budget revenues to GDP), \%.

Note. Hereinafter, the region codes are decrypted in the Table 


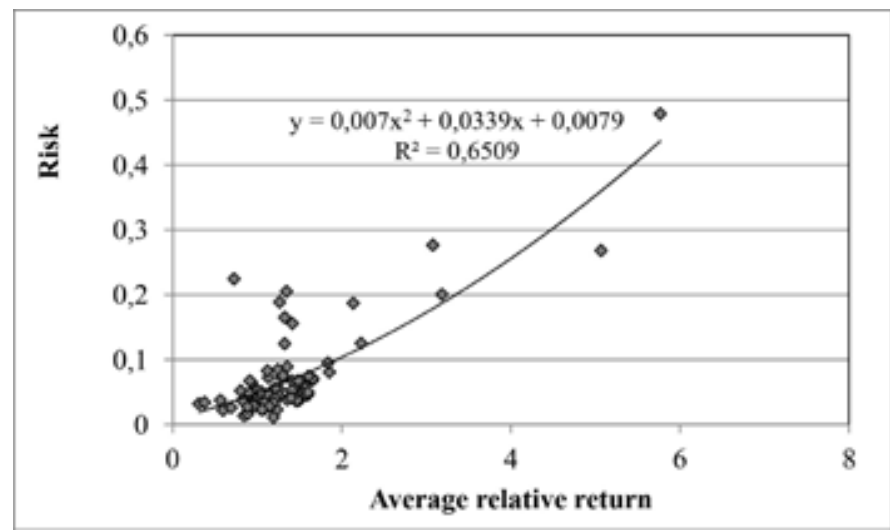

Fig. 2. The relationship between budget return and risk in Russian regions, according to the 1st approach

Table. Assessments of parameters of sustainability of budget revenues in Russian regions

\begin{tabular}{|c|c|c|c|c|c|c|c|}
\hline \multirow{3}{*}{$\begin{array}{c}\text { Subjects of the } \\
\text { Russian Federation }\end{array}$} & \multirow{3}{*}{$\begin{array}{c}\text { Adm. } \\
\text { code } \\
\text { of region }\end{array}$} & \multicolumn{3}{|c|}{ 1st approach } & \multicolumn{3}{|c|}{ 2nd approach } \\
\hline & & $\begin{array}{l}\text { Relative } \\
\text { risk }\end{array}$ & $\begin{array}{l}\text { Growth } \\
\text { of return }\end{array}$ & $\begin{array}{c}\text { Arrow- } \\
\text { Pratt } \\
\text { Function }\end{array}$ & $\begin{array}{l}\text { Relative } \\
\text { risk }\end{array}$ & $\begin{array}{l}\text { Growth } \\
\text { of return }\end{array}$ & $\begin{array}{c}\text { Arrow- } \\
\text { Pratt } \\
\text { Function }\end{array}$ \\
\hline & & 1 & 2 & 3 & 4 & 5 & 6 \\
\hline Altai Krai & 22 & 0.025 & -0.018 & -0.037 & 0.024 & -0.006 & -0.025 \\
\hline Amurskaya Oblast & 28 & 0.149 & -0.044 & -0.156 & 0.151 & -0.032 & -0.145 \\
\hline Arhangelsk Oblast & 29 & 0.043 & -0.021 & -0.054 & 0.043 & -0.007 & -0.040 \\
\hline Astrakhan Oblast & 30 & 0.057 & -0.012 & -0.055 & 0.056 & -0.007 & -0.050 \\
\hline Belgorod Oblast & 31 & 0.047 & -0.025 & -0.060 & 0.048 & -0.027 & -0.063 \\
\hline Bryansk Oblast & 32 & 0.029 & 0.038 & 0.017 & 0.028 & 0.023 & 0.001 \\
\hline Vladimir Oblast & 33 & 0.031 & -0.003 & -0.026 & 0.030 & 0.002 & -0.021 \\
\hline Volgograd Oblast & 34 & 0.043 & -0.007 & -0.040 & 0.043 & -0.002 & -0.034 \\
\hline Vologda Oblast & 35 & 0.032 & -0.004 & -0.027 & 0.032 & -0.001 & -0.025 \\
\hline Voronezh Oblast & 36 & 0.027 & 0.003 & -0.017 & 0.027 & 0.002 & -0.019 \\
\hline Moscow city & 77 & 0.037 & 0.006 & -0.022 & 0.041 & -0.003 & -0.034 \\
\hline St. Petersburg & 78 & 0.035 & -0.011 & -0.038 & 0.037 & -0.032 & -0.060 \\
\hline Jewish Autonomous Oblast & 79 & 0.153 & -0.045 & -0.159 & 0.151 & -0.021 & -0.135 \\
\hline Transbaikal Krai & 75 & 0.044 & -0.029 & -0.061 & 0.043 & -0.013 & -0.045 \\
\hline Ivanovo Oblast & 37 & 0.039 & -0.036 & -0.065 & 0.039 & -0.011 & -0.040 \\
\hline Irkutsk Oblast & 38 & 0.037 & 0.003 & -0.024 & 0.037 & 0.004 & -0.023 \\
\hline $\begin{array}{l}\text { Kabardino-Balkarian } \\
\text { Republic }\end{array}$ & 07 & 0.044 & -0.028 & -0.061 & 0.044 & -0.010 & -0.043 \\
\hline Kaliningrad Oblast & 39 & 0.125 & 0.103 & 0.010 & 0.121 & 0.071 & -0.019 \\
\hline Kaluga Oblast & 40 & 0.028 & 0.013 & -0.009 & 0.029 & 0.008 & -0.013 \\
\hline Kamchatka Krai & 41 & 0.025 & 0.012 & -0.006 & 0.025 & 0.021 & 0.002 \\
\hline Karachay-Cherkess Republic & 09 & 0.088 & 0.018 & -0.048 & 0.088 & 0.008 & -0.058 \\
\hline Kemerovo Oblast & 42 & 0.064 & -0.023 & -0.071 & 0.064 & -0.017 & -0.065 \\
\hline
\end{tabular}


Continued Table

\begin{tabular}{|c|c|c|c|c|c|c|c|}
\hline \multirow{3}{*}{$\begin{array}{c}\text { Subjects of the } \\
\text { Russian Federation }\end{array}$} & \multirow{3}{*}{$\begin{array}{c}\text { Adm. } \\
\text { code } \\
\text { of region }\end{array}$} & \multicolumn{3}{|c|}{ 1st approach } & \multicolumn{3}{|c|}{ 2nd approach } \\
\hline & & $\begin{array}{l}\text { Relative } \\
\text { risk }\end{array}$ & $\begin{array}{l}\text { Growth } \\
\text { of return }\end{array}$ & $\begin{array}{c}\text { Arrow- } \\
\text { Pratt } \\
\text { Function }\end{array}$ & $\begin{array}{l}\text { Relative } \\
\text { risk }\end{array}$ & $\begin{array}{l}\text { Growth } \\
\text { of return }\end{array}$ & $\begin{array}{c}\text { Arrow- } \\
\text { Pratt } \\
\text { Function }\end{array}$ \\
\hline & & 1 & 2 & 3 & 4 & 5 & 6 \\
\hline Kirov Oblast & 43 & 0.040 & -0.040 & -0.070 & 0.038 & -0.016 & -0.044 \\
\hline Kostroma Oblast & 44 & 0.036 & -0.024 & -0.051 & 0.036 & -0.010 & -0.037 \\
\hline Krasnodar Krai & 23 & 0.052 & -0.003 & -0.042 & 0.054 & -0.009 & -0.050 \\
\hline Krasnoyarsk Krai & 24 & 0.065 & -0.014 & -0.063 & 0.065 & -0.023 & -0.072 \\
\hline Kurgan Oblast & 45 & 0.031 & -0.037 & -0.060 & 0.029 & -0.011 & -0.033 \\
\hline Kursk Oblast & 46 & 0.025 & -0.001 & -0.020 & 0.025 & 0.000 & -0.019 \\
\hline Leningrad Oblast & 47 & 0.069 & 0.035 & -0.017 & 0.069 & 0.030 & -0.022 \\
\hline Lipetsk Oblast & 48 & 0.039 & 0.017 & -0.012 & 0.038 & 0.016 & -0.013 \\
\hline Magadan Oblast & 49 & 0.048 & 0.010 & -0.026 & 0.047 & 0.042 & 0.007 \\
\hline Moscow Oblast & 50 & 0.034 & 0.018 & -0.008 & 0.044 & 0.010 & -0.023 \\
\hline Murmansk Oblast & 51 & 0.053 & -0.008 & -0.048 & 0.052 & -0.001 & -0.040 \\
\hline Nenets Autonomous Okrug & 83 & 0.104 & -0.001 & -0.079 & 0.104 & -0.038 & -0.116 \\
\hline Nizhny Novgorod Oblast & 52 & 0.024 & 0.003 & -0.015 & 0.023 & 0.004 & -0.013 \\
\hline Novgorod Oblast & 53 & 0.074 & -0.022 & -0.078 & 0.074 & -0.012 & -0.067 \\
\hline Novosibirsk Oblast & 54 & 0.034 & -0.007 & -0.032 & 0.034 & -0.010 & -0.035 \\
\hline Omsk Oblast & 55 & 0.047 & -0.012 & -0.047 & 0.048 & -0.008 & -0.044 \\
\hline Orenburg Oblast & 56 & 0.033 & -0.018 & -0.043 & 0.034 & -0.012 & -0.038 \\
\hline Oryol Oblast & 57 & 0.043 & -0.012 & -0.044 & 0.043 & -0.001 & -0.033 \\
\hline Penza Oblast & 58 & 0.026 & -0.038 & -0.057 & 0.026 & -0.014 & -0.034 \\
\hline Perm Krai & 59 & 0.016 & -0.010 & -0.022 & 0.016 & -0.008 & -0.021 \\
\hline Primorsky Krai & 25 & 0.045 & -0.025 & -0.059 & 0.045 & -0.021 & -0.055 \\
\hline Pskov Oblast & 60 & 0.031 & -0.041 & -0.064 & 0.032 & -0.014 & -0.038 \\
\hline Republic of Adygea & 01 & 0.041 & -0.007 & -0.038 & 0.041 & -0.006 & -0.037 \\
\hline Altai Republic & 04 & 0.090 & -0.058 & -0.125 & 0.089 & -0.033 & -0.100 \\
\hline Republic of Bashkortostan & 02 & 0.022 & 0.016 & -0.001 & 0.022 & 0.011 & -0.005 \\
\hline Republic of Buryatia & 03 & 0.043 & -0.028 & -0.060 & 0.044 & -0.017 & -0.049 \\
\hline Republic of Dagestan & 05 & 0.030 & 0.015 & -0.007 & 0.031 & 0.001 & -0.022 \\
\hline Republic of Ingushetia & 06 & 0.083 & 0.065 & 0.003 & 0.076 & -0.011 & -0.068 \\
\hline Republic of Kalmykia & 08 & 0.056 & -0.043 & -0.085 & 0.056 & -0.009 & -0.051 \\
\hline Republic of Karelia & 10 & 0.068 & -0.038 & -0.089 & 0.067 & -0.023 & -0.074 \\
\hline Komi Republic & 11 & 0.038 & -0.003 & -0.031 & 0.038 & 0.006 & -0.022 \\
\hline Mari El Republic & 12 & 0.031 & 0.000 & -0.024 & 0.031 & 0.002 & -0.022 \\
\hline Republic of Mordovia & 13 & 0.052 & -0.049 & -0.088 & 0.054 & -0.020 & -0.060 \\
\hline Republic of Sakha (Yakutia) & 14 & 0.038 & 0.044 & 0.016 & 0.039 & 0.065 & 0.036 \\
\hline $\begin{array}{l}\text { Republic of North } \\
\text { Ossetia - Alania }\end{array}$ & 15 & 0.047 & -0.001 & -0.036 & 0.048 & 0.001 & -0.035 \\
\hline Republic of Tatarstan & 16 & 0.029 & 0.006 & -0.016 & 0.029 & 0.001 & -0.021 \\
\hline
\end{tabular}


Continued Table

\begin{tabular}{|c|c|c|c|c|c|c|c|}
\hline \multirow{3}{*}{$\begin{array}{c}\text { Subjects of the } \\
\text { Russian Federation }\end{array}$} & \multirow{3}{*}{$\begin{array}{c}\text { Adm. } \\
\text { code } \\
\text { of region }\end{array}$} & \multicolumn{3}{|c|}{ 1st approach } & \multicolumn{3}{|c|}{ 2nd approach } \\
\hline & & $\begin{array}{l}\text { Relative } \\
\text { risk }\end{array}$ & $\begin{array}{l}\text { Growth } \\
\text { of return }\end{array}$ & $\begin{array}{c}\text { Arrow- } \\
\text { Pratt } \\
\text { Function }\end{array}$ & $\begin{array}{l}\text { Relative } \\
\text { risk }\end{array}$ & $\begin{array}{l}\text { Growth } \\
\text { of return }\end{array}$ & $\begin{array}{c}\text { Arrow- } \\
\text { Pratt } \\
\text { Function }\end{array}$ \\
\hline & & 1 & 2 & 3 & 4 & 5 & 6 \\
\hline Tyva Republic & 17 & 0.063 & 0.014 & -0.033 & 0.064 & -0.001 & -0.049 \\
\hline Republic of Khakassia & 19 & 0.038 & -0.001 & -0.030 & 0.038 & -0.002 & -0.031 \\
\hline Rostov Oblast & 61 & 0.032 & 0.005 & -0.018 & 0.032 & 0.004 & -0.020 \\
\hline Ryazan Oblast & 62 & 0.019 & 0.000 & -0.014 & 0.018 & 0.003 & -0.011 \\
\hline Samara Oblast & 63 & 0.031 & -0.005 & -0.028 & 0.030 & -0.003 & -0.026 \\
\hline Saratov Oblast & 64 & 0.010 & -0.011 & -0.018 & 0.009 & -0.004 & -0.011 \\
\hline Sakhalin Oblast & 65 & 0.310 & 0.078 & -0.154 & 0.313 & 0.302 & 0.067 \\
\hline Sverdlovsk Oblast & 66 & 0.019 & 0.000 & -0.014 & 0.019 & -0.001 & -0.015 \\
\hline Smolensk Oblast & 67 & 0.040 & -0.007 & -0.037 & 0.040 & 0.000 & -0.030 \\
\hline Stavropol Krai & 26 & 0.034 & -0.012 & -0.038 & 0.035 & -0.006 & -0.032 \\
\hline Tambov Oblast & 68 & 0.046 & -0.003 & -0.037 & 0.045 & 0.004 & -0.030 \\
\hline Tver Oblast & 69 & 0.028 & -0.012 & -0.033 & 0.027 & -0.002 & -0.023 \\
\hline Tomsk Oblast & 70 & 0.031 & -0.003 & -0.027 & 0.029 & -0.008 & -0.030 \\
\hline Tula Oblast & 71 & 0.066 & 0.035 & -0.014 & 0.066 & 0.025 & -0.024 \\
\hline Tyumen Oblast & 72 & 0.094 & -0.096 & -0.166 & 0.097 & -0.172 & -0.245 \\
\hline Udmurt republic & 18 & 0.025 & 0.020 & 0.002 & 0.025 & 0.014 & -0.005 \\
\hline Ulyanovsk Oblast & 73 & 0.058 & 0.006 & -0.037 & 0.057 & 0.007 & -0.036 \\
\hline Khabarovsk Krai & 27 & 0.074 & -0.015 & -0.070 & 0.074 & -0.013 & -0.069 \\
\hline $\begin{array}{l}\text { Khanty-Mansi } \\
\text { Autonomous Okrug }\end{array}$ & 86 & 0.091 & -0.004 & -0.072 & 0.089 & -0.036 & -0.102 \\
\hline Chelyabinsk Oblast & 74 & 0.022 & 0.006 & -0.010 & 0.022 & 0.003 & -0.013 \\
\hline Chechen Republic & 20 & 0.053 & -0.269 & -0.309 & 0.055 & -0.071 & -0.113 \\
\hline Chuvash Republic & 21 & 0.030 & -0.004 & -0.026 & 0.030 & 0.000 & -0.023 \\
\hline $\begin{array}{l}\text { Chukotka Autonomous } \\
\text { Okrug }\end{array}$ & 87 & 0.110 & 0.080 & -0.003 & 0.111 & 0.248 & 0.165 \\
\hline $\begin{array}{l}\text { Yamal-Nenets } \\
\text { Autonomous Okrug }\end{array}$ & 89 & 0.067 & -0.005 & -0.055 & 0.063 & -0.034 & -0.081 \\
\hline Yaroslavskaya oblast & 76 & 0.047 & -0.020 & -0.055 & 0.047 & -0.014 & -0.048 \\
\hline
\end{tabular}

are the majority of subjects of Far Eastern Federal District: first of all, Sakhalin Oblast $\left(v_{r}=0.310\right)$, followed by Jewish Autonomous Oblast (0.153), Amur Oblast (0.149), and Chukotka Autonomous Okrug (0.110). Among the regions with a higher level of sub-federal budget relative risk (0.125), we also find Kaliningrad Oblast, which is the westernmost subject of the Russian Federation. It is noteworthy that the most risky are again the border areas. In addition, the main extracting regions and the underdeveloped southern republics also show an increased relative risk of sub-federal budgets, but its assessments turned out to be slightly lower.

The most stable are still the sub-federal budgets of Saratov Oblast $\left(v_{r}=0.010\right)$, Perm Krai (0.016) and Sverdlovsk Oblast (0.019). A 
low relative risk of the sub-federal budget is also observed in Ryazan Oblast (0.019).

As we noted in the methodological part of this paper, for sub-federal budgets, not only the stability of returns, but also their steady growth rates are important. According to column 2 of the Table, only 27 out of 83 regions showed positive dynamics in the relative return of sub-federal budgets. Moreover, the leaders here are the regions previously marked as the most unstable, namely Kaliningrad and Sakhalin Oblasts, Chukotka AO, as well as Republic of Ingushetia. Obviously, this property should improve the position of these regions when assessing the sustainability of budget systems based on the Arrow-Pratt function.

At the same time, Chechen Republic has the largest negative dynamics in relative budget return $\left(\alpha_{1}=-0.269\right)$. It is followed by Tyumen Oblast (-0.096) and Altai Republic (-0.058) with a wide margin.

According to the Pearson linear coefficient, the correlation between relative risk and steady growth rate of relative return of sub-federal budgets is very low and unstable $(R=0.162)$. Therefore, we cannot unambiguously predict a change in the position of the regions, given both parameters in the selected utility function.

The obtained assessments of the Arrow-Pratt function are presented in column 3 of the Table. They indicate that Bryansk Oblast $(f=0.017)$, Republic of Sakha-Yakutia (0.016) and Kaliningrad Oblast (0.010) have the most efficient budget systems. At the same time, the ratings of Chechen Republic $(f=-0.309)$, Tyumen Oblast (-0.166), Jewish AO (-0.159), Amur Oblast (-0.156) and Sakhalin Oblast $(-0.154)$ are the lowest among all. In these regions (except the last), the increased risk of relative budget returns is also accompanied by the negative dynamics of this indicator.

Now we present the results of the estimation of functions (4) within the second approach. Fig. 3 shows the evaluation of absolute risk of sub-federal budgets calculated for relative real per capita budget revenues. Among the most risky by this indicator are Sakhalin Oblast (here the absolute risk is $85.4 \%$ with a relative budget return of 272.9\%), Chukotka Autonomous Okrug (with risk of $46.1 \%$, and return of $415.0 \%$ ), Nenets Autonomous Okrug (41.1\%, and 395.3\%). All these regions specialize in the mining industry, so their budget revenues are highly dependent on the global environment in the energy markets.

The least risky in terms of volatility of relative real budget revenue per capita are Saratov Oblast (which risk is $0.6 \%$, and relative return is $68 \%$ ), Perm Krai $(1.2 \%$ and $75.4 \%)$, Ryazan Oblast (1.3\% and $73.3 \%)$, and Sverdlovsk Oblast (1.5\% and 81.4\%). All of them are located in the European part of Russia or at the junction of Europe and Asia.

For the second approach, we also found a positive relationship between the average level of relative budget return and its risk (Fig. 4). The outlier in the figure is presented by Sakhalin Oblast, which demonstrates an abnormally high level of budget risk. Since the relative return indicators involved in the 1st and 2nd approaches differ in content, the correlation of their absolute risk assessments is low $(\mathrm{R}=0.361)$. Meanwhile, both indicators in the numerator have sub-federal budget revenues; therefore, the relationship between risk assessments turned out to be positive, although weak in strength.

Relative risk, calculated as the ratio of absolute risk to average relative budget return under the second approach, is presented in column 4 of the Table. The highest relative risk is observed in Sakhalin Oblast (0.313), Amur Oblast (0.151), Jewish AO (0.151), Chukotka Autonomous Okrug (0.111) and Kaliningrad Oblast (0.121). These are the same regions that were identified as the most risky in the first approach. The lowest relative risk was again obtained in Saratov Oblast (0.009), Perm Krai (0.016), Ryazan Oblast (0.018) and Sverdlovsk Oblast (0.019). In general, the correlation of the relative risk assessments received on the basis of the two approaches turned out to be very high $(\mathrm{R}=0.999)$.

The dynamics of the relative real budget revenues per capita (column 5 of the Table) also showed a close relationship with the dynamics of relative budget revenues to GRP in the re- 


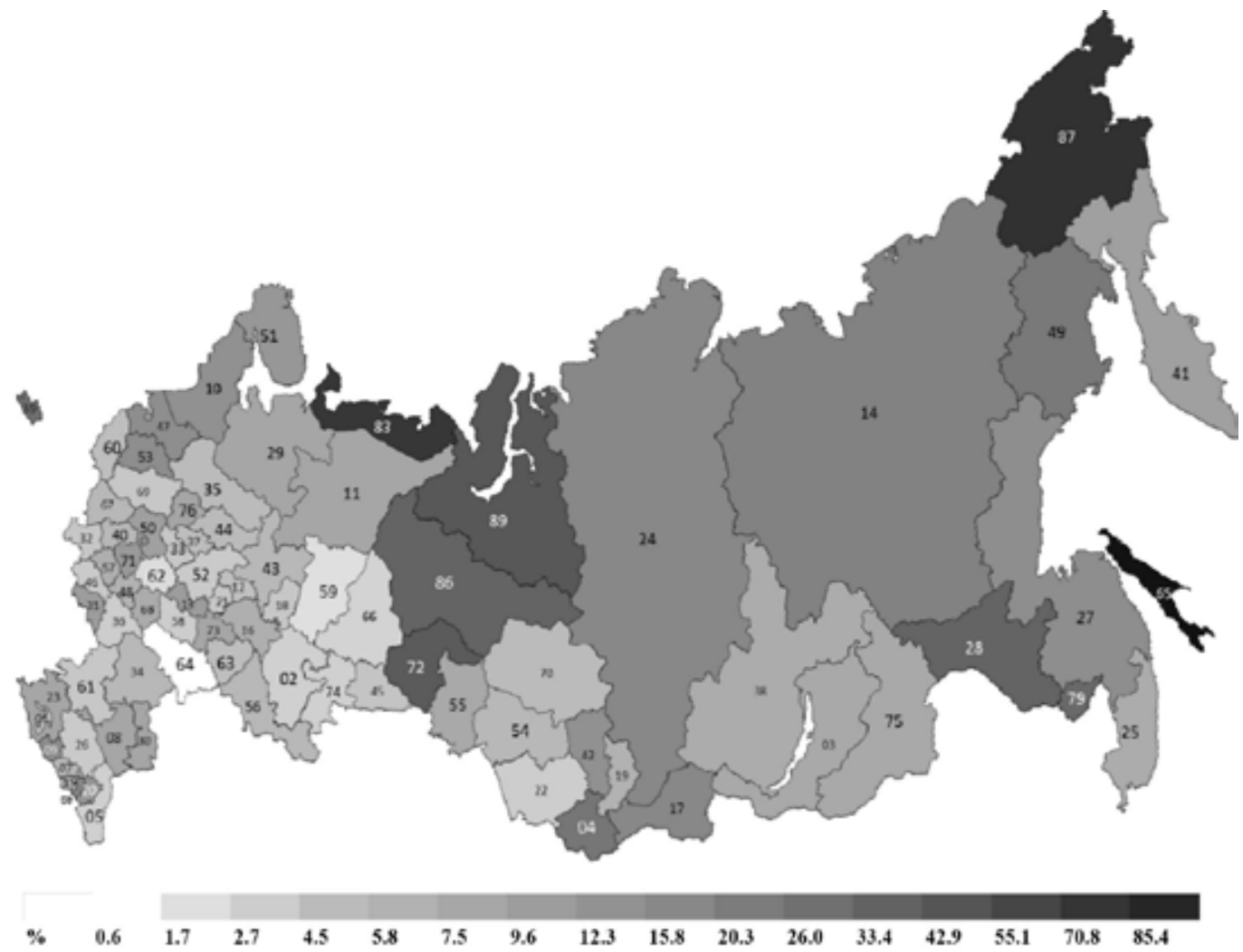

Fig. 3. Absolute risk of sub-federal budgets

(measured on the basis of real budget revenue per capita), \%

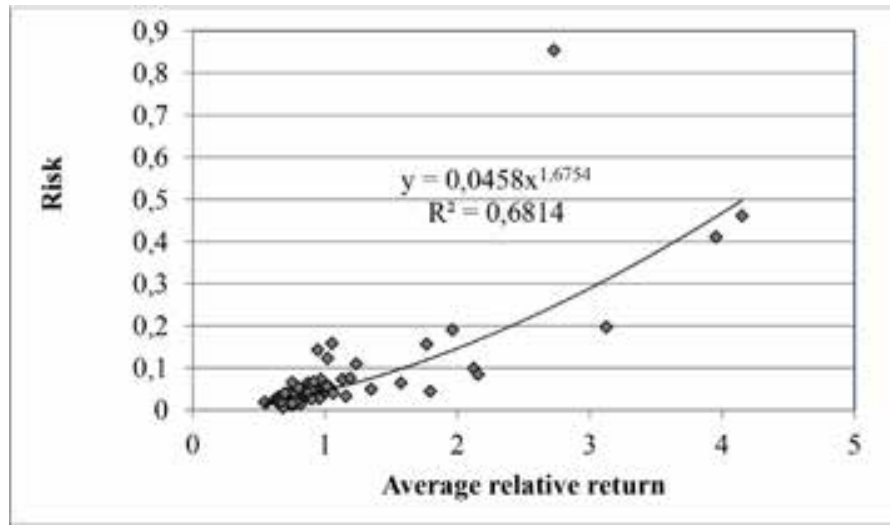

Fig. 4. The relationship between budget return and risk in Russian regions, according to the 2nd approach

gions (column 2). Their linear correlation coefficient is $\mathrm{R}=0.622$. At the same time, according to the 2nd approach, the number of regions with positive dynamics of relative budget return is somewhat larger ( 30 versus 27 , according to the 1st approach).

The assessments of the Arrow-Pratt function obtained by the 2 nd approach are presented 
in column 6 of the Table. For most regions, we do not find any significant discrepancies with the results of the 1st approach. The linear correlation coefficient of the two assessments of the Arrow-Pratt function is 0.609. Meanwhile, for some regions, assessments of A-P functions vary greatly. First of all, we mean Sakhalin Oblast, which demonstrates one of the worst values of the Arrow-Pratt function (79th out of 83th) according to the first approach and takes 2nd place in the second approach. In Republic of Ingushetia, the situation is the opposite. According to the Arrow-Pratt function, estimated on the basis of the relative budget income to GRP, the republic is one of the leaders and takes the 4th place, and it is one of the most lagging (72th), when the A-P function is based on real income per capita. The calculation of the average rank of budget sustainability (as the arithmetic mean of the ranks obtained for the two A-P functions) shows that the leaders in this indicator are Republic of Sakha (rank 2.5), Bryansk Oblast (3.5) and Chukotka Autonomous Okrug (4). The lowest financial sustainability is demonstrated by Tyumen Oblast (whose rank is 82.5), Amur Oblast, Jewish AO and Chechen Republic (with an average rank of 81 each).

\section{Conclusion}

This study is devoted to the development of the concept and methodology for assessing the sustainability of budget revenues of terri- torial entities. By sustainability we mean both stability (low volatility) and a steady growth rate of real budget revenues relative to GRP and per capita compared with the average country indicators, which allows to eliminate the system-wide risk. For a comprehensive assessment of budget revenues sustainability, we proposed using the Arrow-Pratt function. Based on this methodology, we calculated the absolute and relative risk and steady growth rates of relative budget returns, as well as the level of sustainability of budget revenues in 83 Russian regions. Assessments obtained for the two alternative indicators turned out to be highly correlated, with some outstanding exceptions.

The results are consistent with the logic of economic processes. We found that the most vulnerable are the budget systems of either underdeveloped regions or regions whose incomes depend on the global situation. The spatial location of such regions is also noteworthy. Almost all of them are located on the outskirts of the Russian Federation and are border territories. At the same time, some inland mining areas, by contrast, may exhibit increased sustainability. Republic of Sakha is a good example of such a region, while Tyumen Oblast is a typical exception. A deeper understanding of the origin of fiscal instability in certain regions requires its decomposition by industry or revenue component, which may be the subject of future analysis.

\section{References}

Andryakov, A.D. (2017). Sbalansirovannost' i ustoichivost' regional'nykh biudzhetov v 2008-2016 gg. [Balance and Sustainability of Regional Budgets in 2008-2016]. In Finansovyi zhurnal [Financial Journal], 6, 25-39.

Bohn, H. (2008). The sustainability of fiscal policy in the United States. In R. Neck, \& J. Sturm (Eds.), Sustainability of public debt. MIT Press, 15-49.

Bozhechkova, A.V., Mamedov, A.A., Sinelnikov-Murylev, S.G., Turuntseva M.Yu. (2018). Stabilizatsionnye svoistva transfertov, vydeliaemykh regionam Rossii iz federal'nogo biudzheta [Stabilization Properties of Federal Fiscal Transfers to Russian Regions]. In ZHurnal Novoi ekonomicheskoi assotsiatsii [Journal of the New Economic Association], 4 (40), 61-83. DOI: 10.31737/2221-2264-201840-4-3.

Di Bella, G., Dynnikova, O., Grigoli, F. (2018). Fiscal federalism and regional performance in Russia. In Russian Journal of Economics, 4, 108-132. DOI: 10.3897/j.ruje.4.27741.

Gambarov, G., Musayeva, M., Krupkina, A. (2017). Indikator riskov rossiiskogo finansovogo rynka [Russian Financial Market Risk Index]. In Money and Credit [Den'gi i kredit], 6, 29-38. 
Ivanov, P.A., Sakhapova, G.R. (2014). Finansovaia nestabil'nost' regiona: metody otsenki i instrumenty eliminirovaniia [Financial instability in the region: assessment methods and elimination tools]. In Ekonomicheskie i sotsial'nye peremeny: fakty, tendentsii, prognoz [Economic and social changes: facts, trends, forecast], 6 (36), 183-198. DOI: 10.15838/esc/2014.6.36.14.

Klimanov, V.V., Kazakova, S.M., Mikhaylova, A.A. (2019). Retrospektivnyi analiz ustoichivosti regionov Rossii kak sotsial'no-ekonomicheskikh sistem [Retrospective analysis of the resilience of Russian regions as socio-economic systems]. In Voprosy Ekonomiki, 5, 46-64. DOI: 10.32609/0042-8736-2019-546-64.

Klimanov, V.V., Kazakova, S.M., Mikhaylova, A.A. (2018). Regional'naia rezilientnost': teoreticheskie osnovy postanovki voprosa [Regional Resilience: Theoretical Basics of the Question]. In Ekonomicheskaya politika [Economic Policy], 13 (6), 164-187. DOI: 10.18288/1994-5124-2018-6-164-187.

Malkina, M.Yu. (2018a). Nestabil'nost' finansovoi dokhodnosti regional'nykh ehkonomik i ee determinanty [Instability of financial return of regional economies and its determinants]. In Prostranstvennaya ehkonomika [Spatial Economics], 3, 88-114. DOI: 10.14530/se.2018.3.088-114.

Malkina, M.Yu. (2018b). Vklad regionov i otraslei v finansovuiu nestabil'nost' rossiiskoi ekonomiki [Contribution of regions and their sectors to the financial instability of the Russian economy]. In Terra Economicus, 16 (3), 118-130. DOI: 10.23683/2073-6606-2018-16-3-118-130.

Malkina, M.Yu. (2019). How change in industry mix can improve the financial performance of regional economies: evidence from the portfolio approach. In Acta Universitatis Agriculturae et Silviculturae Mendelianae Brunensis, 67 (6), 1561-1575. DOI: 10.11118/actaun201967061561.

Rahma, H., Fauzi, A., Juanda, B., Widjojanto, B. (2019). Development of a Composite Measure of Regional Sustainable Development in Indonesia. In Sustainability, 11, 5861. DOI:10.3390/su11205861.

Sheremeta, S.V. (2020). Analiz regional'nykh finansov Rossii i ustoichivost' dolga regionov [Russian regional finances analysis and regional debt sustainability]. In Voprosy Ekonomiki, 2, 30-58. DOI: 10.32609/0042-8736-2020-2-30-58.

Smetana, S. Tamásy, C. Mathys, A. Heinz, V. (2015). Sustainability and regions: sustainability assessment in regional perspective. In Regional Science Policy and Practice, 7 (4), 163-186. DOI: 10.1111/ rsp3.12068. 


\title{
Оценка устойчивости бюджетных доходов регионов Российской Федерации
}

\author{
М.Ю. Малкина \\ Нижегородский государственный университет \\ им. Н.И. Лобачевского \\ Российская Федеращия, Нижний Новгород
}

\begin{abstract}
Аннотация. В статье предложены новые подходы к оценке устойчивости бюджетных доходов региона, которые апробированы на примере 83 субъектов Российской Федерации в 2010-2017 годах. Устойчивость доходов бюджета оценивается на основе временных рядов двух показателей: отношения доходов субфедеральных бюджетов к ВРП региона и реальных доходов субфедеральных бюджетов в расчете на душу населения. Для исключения эффекта масштаба и устранения общесистемного риска оба показателя рассчитываются как отношение к среднероссийским значениям. С помощью построения временных линейных регрессий определяются устойчивый темп роста, абсолютный риск и относительный риск бюджетных доходов. Для комплексной оценки устойчивости доходов бюджета в регионе мы предложили использовать функцию Эрроу-Пратта с включенным параметром неприятия риска 1,5.

С использованием предложенной методики мы оценили абсолютный и относительный риск, а также устойчивость доходов бюджета в российских регионах. Оценки, полученные на основе двух альтернативных показателей, продемонстрировали высокую корреляцию. Наше исследование выявило, что наименее устойчивые бюджетные системы характерны как для некоторых приграничных регионов, включая отсталые республики Северного Кавказа и регионы Дальнего Востока с нестабильной экономикой, так и для достаточно развитой, но зависящей от мировой конъюнктуры Тюменской области. В то же время некоторые добывающие регионы (Республика Саха), напротив, продемонстрировали высокую устойчивость бюджетных поступлений.
\end{abstract}

Ключевые слова: финансовая устойчивость, регион, субфедеральный бюджет, доходы бюджета, риск и доходность бюджетной системы.

Работа выполнена при финансовой поддержке РФФИ в рамках реализации проекта № 19-010-00716 «Разработка методологии и нетрадиционных методов оценки финансовой нестабильности».

Научная специальность: 08.00.00 - экономические науки. 